http://dx.doi.org/10.12775/szhf.2016.030

\author{
RAFA£ MichalsKi \\ Uniwersytet MikoŁaja Kopernika, Toruń, Polska \\ METABASIS1@WP.PL
}

\title{
Paradoksy freudowskiej teorii wyparcia Część I
}

\section{Wstęp}

Niezależnie od tego, jak ostatecznie ocenimy poznawczą (i terapeutyczną) wartość psychoanalizy, chcąc nie chcąc, musimy zaakceptować fakt, że wywarła ona ogromy wpływ na współczesną humanistykę i na potoczny sposób myślenia o zjawiskach psychicznych ${ }^{1}$. Wydaje się, że mimo istnienia nieprzebranej literatury fachowej, zarówno czysto egzegetycznej, jak i krytycznej bądź też twórczo nawiązującej do dziedzictwa Freuda, jego myśl w swoich teoretycznych fundamentach pozostaje wciąż obszarem w niewystarczający sposób zbadanym, domagającym się bardziej uważnego, „źródłowego” przyswojenia. Już sam przegląd tytułów najważniejszych opracowań pokazuje, że w recepcji psychoanalizy dominują dwie strategie: strategia krytyczna, demaskująca teoretyczne nadużycia, oraz strategia, w której myśl Freuda funkcjonuje jako inspiracja, a nierzadko po prostu jako pretekst do rozwija-

${ }^{1}$ Recepcję psychoanalizy we współczesnej filozofii omawia m.in.: Z. Rosińska, Freud, Warszawa 2002, s. 105-158; P. Ricoeur, O interpretacji. Esej O Freudzie, przeł. M. Falski, Warszawa 2008, s. 321-386. 
nia własnych - często bardzo interesujących - koncepcji, niemających jednak wiele wspólnego ze swoim pierwowzorem. Badania nad psychoanalizą $\mathrm{w}$ Polsce prezentują się zdecydowanie skromniej niż za granicą (nie tylko w Niemczech, we Francji, w krajach anglosaskich, lecz również we Włoszech, w Hiszpanii, a nawet w Japonii). O „urwanych ścieżkach” recepcji psychoanalizy w naszym kraju pisał szczegółowo Paweł Dybel, dlatego pominiemy tutaj ten wątek, odsyłając zainteresowanego czytelnika do literatury przed$\mathrm{miotu}^{2}$. Tytułem wstępu chcielibyśmy natomiast wskazać główny cel niniejszego artykułu, jakim jest zaproszenie do źródłowej, „przyjaznej”, choć ostatecznie krytycznej lektury tekstów Freuda. Wszystkie polskie przekłady, na których opierają się poniższe analizy zostały porównane z niemieckim oryginałem ${ }^{3}$. Czytanie freudowskiego corpus w języku polskim stało się możliwe dopiero ostatnimi czasy dzięki wieloletniej, żmudnej pracy translatorskiej Roberta Reszke, Jerzego Prokopiuka oraz innych tłumaczy. Przekład nastąpił wprawdzie z dużym opóźnieniem, ale właśnie z tego powodu należałoby zintensyfikować i podjąć na nowo interpretację wciąż mało znanego w Polsce dzieła, które jest wysoce złożone, niejednoznaczne, pełne sprzeczności i - co najważniejsze - zawiera szereg fundamentalnych dla naszej współczesnej samowiedzy rozpoznań. Przy tej okazji nasuwa się oczywiście podstawowe pytanie: od czego zacząć? na czym się skupić?

Pisma Freuda są trudne ze względu na nieprecyzyjnie zdefiniowaną i niesystematycznie stosowaną terminologię, a przede wszystkim dlatego, że rozwijana przez niego teoria aparatu psychicznego podlegała licznym modyfikacjom, które bynajmniej nie wykrystalizowały się w jakąś spójną pojęciowo całość. Pojęcia, za pomocą których Freud opisuje ludzką psychikę, tworzą swoisty system naczyń połączonych ${ }^{4}$. Rekonstruując znaczenie dowolnego terminu technicznego, siłą rzeczy zmuszeni jesteśmy odwoływać się tutaj do innych pojęć, a szerzej - do całości systemu. W ten sposób przed interpreta-

${ }^{2}$ P. Dybel, Psychoanaliza - ziemia obiecana? Dzieje psychoanalizy w Polsce 1900-1989. Część pierwsza: Okres burzy i naporu, Kraków 2016.

${ }^{3}$ Nie podaję w tym miejscu tytułów tekstów Freuda, na których bazuje moja interpretacja, ze względu na ich pokaźną liczbę. Wszystkie tytuły zostaną szczegółowo wymienione i bibliograficznie opisane w toku wywodów. W artykule uwzględniam te teksty, w których Freud explicte omawia zagadnienie wyparcia. Dużym ułatwieniem w opracowaniu tematu było to, że większość jego tekstów dostępna jest w formie cyfrowej.

${ }^{4} \mathrm{~W}$ artykule skupiam się na rekonstrukcji przysłowiowego „co autor ma na myśli” i przyjmuję zastosowane przez niego (metaforyczne w większości przypadków) pojęcia za bezdyskusyjny punkt wyjścia. Analiza „retorycznego” wymiaru jego wywodów wymagałaby, jak sądzę, napisania odrębnego artykułu. Zatem celowo rezygnuję tutaj z omawiania tej problematyki. 
torem otwiera się klasyczne koło hermeneutyczne, dialektyka części i całości. Dlatego też zalecane byłoby w tym przypadku zastosowanie się do uwagi Gadamera:

W taki właśnie sposób - zawsze od całości do części i z powrotem do całości przebiega ruch naszego rozumienia. Jego zadanie polega na rozszerzaniu na kolejne kręgi jedności rozumianego sensu. Zestrojenie wszystkich szczegółów w całość jest w każdym przypadku probierzem rozumienia. Brak takiego zestroju równa się niepowodzeniu próby rozumienia ${ }^{5}$.

W przypadku Freuda „zadanie rozumienia” wydaje się szczególnie trudne, gdyż, jak już wspomniano, jego system nie stanowi spójnej całości. Dlatego interpretacja wymaga stopniowego i nieuchronnie narażonego na błędy zbliżania się do poszukiwanego sensu, które musi oscylować pomiędzy wstępnym rozumieniem całości a żmudną analizą szczegółową. Dopiero tego rodzaju, niekiedy „błądzące po omacku”, zestrajanie poszczególnych części z całością pozwoli interpretatorowi rozjaśnić znaczenie danego szczegółu (pojęcia) i doprecyzować obraz całego systemu.

Za punkt wyjścia na drodze do „rozumienia sensu” projektu Freuda wybrałem pojęcie wyparcia, które stanowi jedną z najbardziej kluczowych kategorii psychoanalizy. Za jego pomocą autor Objaśniania marzeń sennych wyjaśnia etiologię schorzeń psychicznych, powstawanie traumy, rozdział na proces pierwotny i wtórny, a także topiczny model psychiki (ego, superego, id). Na potrzeby niniejszego artykułu możemy zatem przyjąć tezę, że wyparcie jest podstawową kategorią, niejako ośrodkiem krystalizacji wszystkich teoretycznych, ale również klinicznych zabiegów freudowskiej psychoanalizy. Podejmujemy zarazem w nim wezwanie, wyrażone wcześniej przez Lacana w postaci hasła „z powrotem do Freuda”. Powrót rozumiemy jednak dosłownie jako ponowną, immanentną (skoncentrowaną na wewnętrznej analizie, a zatem pozbawioną porównań $\mathrm{z}$ innymi koncepcjami) lekturę podstawowych tekstów twórcy psychoanalizy. Nieocenioną i ze wszech miar godną polecenia pomocą ułatwiającą orientację w gąszczu odesłań i pourywanych wątków zawartych we freudowskim dziele okazał się obszerny (ponad 1200

${ }^{5}$ H. G. Gadamer, Koło jako struktura rozumienia, przeł. G. Sowinski, [w:] tenże, Wokół rozumienia. Studia i szkice z hermeneutyki, Kraków 1993, s. 227. 
stron) i znakomicie opracowany Wörterbuch der Psychoanalyse Élisabeth Roudinesco i Michela Plona ${ }^{6}$.

Już na samym początku rekonstrukcji teorii wyparcia natknęliśmy się na podstawową sprzeczność, która pojawia się w rozmaitych ujęciach i korektach wprowadzanych przez Freuda w kolejnych artykułach: sprzeczność między tezą, że instancją wypierającą jest (częściowo świadome) Ja, a założeniem, że wyparcie polega ostatecznie na całkowitym wykluczeniu tego, co wyparte z obszaru świadomości. Freud próbował rozwiązać wskazany paradoks, nieustannie modyfikując swoją koncepcję, jednakże usiłowania te zakończyły się fiaskiem. Do pewnego stopnia był świadomy omawianych przez nas trudności, niemniej jednak do końca pozostał wierny swojej pierwotnej intuicji, która znajdowała potwierdzenie w klinicznej praktyce, a nie w teoretycznych rozważaniach. Uprzedzając wyniki późniejszych analiz, możemy zatem powiedzieć, że w koncepcji wyparcia prymat nad teorią uzyskał impuls praktyczny. Jeśli nawet „przyjaźnie” zaakceptujemy tak ustawione priorytety badawcze i zgodzimy się z Freudem, że ostatni głos w psychoanalizie ma obserwacja, a nie wymogi czysto teoretyczne, to jednak nie uwolnimy się dzięki temu od ciężaru kłopotliwego pytania o trafność diagnozy i skuteczność terapii psychoanalitycznej. W niniejszym artykule celowo pomijamy wskazaną trudność, ponieważ interesuje nas przede wszystkim pojęciowy aspekt koncepcji wyparcia, a szerzej - jej filozoficzny wymiar. Pomimo usilnych starań mających na celu możliwie zwięzłe przedstawienie tej teorii, jej rekonstrukcja okazała się na tyle obszerna, że niezbędne stało się rozbicie całości tekstu na dwa odrębne artykuły.

Kończąc wstępne rozważania, chciałbym jeszcze podzielić się uwagą natury terminologiczno-translatorskiej. Podstawą niniejszych analiz jest przekład dzieł Freuda autorstwa Roberta Reszke (porównywany z niemieckim oryginałem), jednakże niekiedy odwołuję się również do tłumaczeń Jerzego Prokopiuka. Nie czynię tego jednak, ponieważ uznaję, że jego przekład jest „lepszy” merytorycznie, lecz kieruję się w tych przypadkach wyłącznie względami czysto stylistycznymi. Dotyczy to na przykład takich terminów jak: ego (Ja), id (To), superego (Nad-Ja), ponadto zdarza się, że to samo dzieło Freuda cytowane jest $\mathrm{z}$ dwóch różnych przekładów. Mam nadzieję, że ten nieco samowolny i niefrasobliwy zabieg nie wpłynął istotnie na zawartość treściową analiz i spotka się z wyrozumiałą akceptacją czytelnika.

${ }^{6}$ É. Roudinesco, M. Plon, Wörterbuch der Psychoanalyse, przeł. Ch. Eissing-Christophersen, M. Müllerburg, R. Nentwig, M. Ramaharomanana, F. Roelcke, M. Wiesmüller, Wien 2004. 


\section{Paradoksy teorii wyparcia w topicznym modelu psychiki}

Bez wątpienia kategoria wyparcia odgrywa fundamentalną rolę w teoretycznym projekcie Freuda, który jednoznacznie uznał, że pojęcie to stanowi najstarszy fragment terminologii psychoanalitycznej ${ }^{7}$. To właśnie z teorii wyparcia, jak sam przyznaje, psychoanaliza wyprowadziła kluczowe pojęcie nieświadomości, a zjawisko tego, co wyparte (das Verdrängte) stało się modelem tego, co nieświadome ${ }^{8}$. Ponadto mechanizm wyparcia „okazał się głównym czynnikiem powodującym powstanie tak zwanych psychonerwic" ${ }^{\prime \prime}$ Nie ma potrzeby potwierdzać $\mathrm{w}$ materiale źródłowym spostrzeżenia, że pojęcie to było wykorzystywane przez Freuda w opisie rozwoju psychoseksualnego. Wyparte pobudzenie zostało uznane przez niego za źródło wszelkiej traumy, dlatego możemy bez obaw postawić tezę, że Verdrängung stanowi kwintesencję nie tylko teoretycznych konstrukcji, ale przede wszystkim - klinicznej praktyki psychoanalizy. Wiele wskazuje na to, że autor Objaśniania marzeń sennych traktował to pojęcie jako własny, nowatorski wkład do psycholo$\mathrm{gii}^{10}$. W wielu miejscach wskazywał wprawdzie, że pojęcie nieświadomości (a zatem i wyparcia) było od dawna obecne w psychologicznej i filozoficznej tradycji, ale nikt przed nim nie zwrócił uwagi na całkowitą odrębność i niedostępność nieświadomych wyobrażeń dla świadomych procesów. W perspektywie historii idei pogląd ten nie jest bynajmniej słuszny w całej rozciągłości. O ile możemy jeszcze zgodzić się z tym, że stosuje się on, na przykład, do leibnizjańskiej teorii „nieświadomych” (a ściślej - ledwo dostrzegalnych) les petites - „ciemnych” percepcji, o tyle nie wydaje się już trafny w odniesieniu do często przytaczanej w tym kontekście platońskiej koncepcji duszy pożądliwej (epithymētikón) lub - jeśli posłużymy się mniej znanym przykładem - do kantowskiej teorii nieświadomości. W Antropologii w ujęciu pragmatycznym Kant opisuje rozwój samoświadomości jako proces przebiegający na „mrocznym” tle afektów, nieświadomych wyobrażeń, które nieustannie

\footnotetext{
${ }^{7}$ Z. Freud, Fetyszyzm, przeł. R. Reszke, [w:] tenże, Psychologia nieświadomości, Warszawa 2009, s. 306. W wydanej rok wcześniej (1926) rozprawie Freud przypomina, że zrezygnował ostatecznie z używanego wcześniej terminu odparcie (Abwehr) i zastąpił je pojęciem wyparcia. Por. Z. Freud, Zahamowanie, symptom, lęk, [w:] tenże, Histeria i lęk, przeł. R. Reszke, Warszawa 2001, s. 264.

${ }^{8}$ Tenże, Ego i id, przeł. J. Prokopiuk, [w:] Z. Rosińska, Freud..., s. 297.

9 Tenże, Dowcip i jego stosunek do nieświadomości, przeł. R. Reszke, Warszawa 1993, s. 128.

${ }^{10}$ Por. tenże, Wyparcie, przeł. M. Poręba, [w:] Z. Rosińska, Freud..., s. 259.
} 
zagrażają budzącej się do życia rozumnej części duszy i są dla niej całkowicie niedostępne:

Że pole naoczności zmysłowych i wrażeń, których nie jesteśmy świadomi [...], to jest pole niejasnych przedstawień w człowieku (również i w zwierzęciu) jest niezmierzone, natomiast jasne przedstawienia zajmują $\mathrm{w}$ nim tylko nieskończenie mało punktów dostępnych świadomości, że niejako na mapie naszego umysłu tylko nieliczne miejsca są oświetlone, wzbudza w nas podziw dla naszej własnej istoty ${ }^{11}$.

Problem wyparcia uwzględnił dość jednoznacznie już Schopenhauer w 32 paragrafie Świata jako woli i przedstawienia, rozważając naturę obłędu:

Jeśli natomiast choć w jednym jedynym przypadku opór i przeciwdziałanie [podkr. R. M.] woli, by nie przyjąć jakiegoś poznania, osiągnie taki stopień, że operacja nie zostanie dokonana prawidłowo, jeśli więc nastąpi zupełne przemilczenie jakichś zdarzeń lub okoliczności, gdyż ich widok jest dla woli nieznośny, wtedy powstałą w ten sposób lukę w koniecznym związku wypełnia się zupełnie dowolnie - i oto mamy obłęd ${ }^{12}$.

Niezależnie od tego, jak ostatecznie ocenimy rzekomą innowacyjność psychoanalizy, musimy przyjąć, że dla Freuda najważniejszym elementem jego „odkrycia” było powiązanie mechanizmu wyparcia z reakcją „oporu” wobec świadomości ${ }^{13}$. Wielokrotna obserwacja owego oporu w praktyce terapeutycznej skłoniła go do radykalnego zerwania z tradycyjnym modelem umysłu jako podmiotu refleksyjnej samoświadomości oraz do większego zniuansowania pojęcia nieświadomości ${ }^{14}$. Okazało się bowiem, że główny cel terapii, czyli uświadomienie wypartych treści, nie daje się zrealizować za pośrednictwem tradycyjnych środków - introspekcji, autorefleksji, racjonalnego porozumienia, dedukcji etc.

${ }^{11}$ I. Kant, Antropologia w ujęciu pragmatycznym, przeł. E. Drzazgowska, P. Sosnowska, Warszawa 2005, s. 22.

12 A. Schopenhauer, Świat jako wola i przedstawienie, t. 2, przeł. J. Garewicz, Warszawa 1995, s. 575. Laplanche i Pontalis wskazują, że termin „wyparcie” pojawił się u Johanna F. Herbarta w: J. Laplanche, J. B. Pontalis, Słownik psychoanalizy, przeł. E. Modzelewska, E. Wojciechowska, Warszawa 1996, s. 370.

${ }^{13}$ Por. Z. Freud, Ego i id..., s. 299-300.

${ }^{14}$ Tenże, Poza zasadą przyjemności, przeł. J. Prokopiuk, Warszawa 2000, s. 17. 
Aby uchwyć właściwy sens wyparcia w psychoanalizie Freuda, należy uwzględnić dwie przeplatające się $\mathrm{w}$ niej perspektywy opisu: perspektywę "czysto” teoretyczną, zorientowaną na stworzenie spójnego, systematycznego modelu aparatu psychicznego, oraz na perspektywę „kliniczną”, której celem jest osiągnięcie praktycznego celu terapii, czyli przywrócenie zdrowia psychicznego pacjenta. Obydwie strategie interpretacyjne wzajemnie uzupełniają się i uzasadniają, ale również, co spróbujemy wykazać w dalszej części wywodu, niekiedy przeczą sobie, prowadząc do nierozwiązywalnych komplikacji. Najbardziej problematyczny wydaje się wpisany w mechanizm wyparcia moment wykluczenia traumatycznego impulsu z pola świadomości. Problem ten dobrze ilustruje rozróżnienie pojęcia wyparcia i odrzucenia (lub potępienia), które znajdziemy w 19 wykładzie Wstępu do psychoanalizy (1917). Freud stwierdza tam, że odrzucenie polega na zahamowaniu impulsu popędowego lub myślowego, który traci w ten sposób możliwość przekształcenia się w realne działanie. Tego rodzaju blokada pozbawia pierwotny impuls energii psychicznej, czyni go bezwładnym, jednakże nie odcina go od świadomości. Odrzucone pragnienie, chęć czy myśl pozostają przez cały czas dostępne $\mathrm{w}$ postaci wspomnienia. Inaczej rzecz ma się $\mathrm{z}$ wyparciem. W tym przypadku „proces decyzyjny” przebiega nieświadomie, a wyparty impuls zachowuje pierwotną energię, przechodzi niejako w stan uśpienia ${ }^{15}$. Freud odwołuje się tutaj do wcześniejszego artykułu z 1915 roku, w którym stwierdza, że istota wyparcia „[...] polega jedynie na odrzucaniu (Abweisung) bodźca i trzymaniu go z dala od obszaru świadomości" ${ }^{\prime \prime}$. Jednakże ta - uznawana często w literaturze tematu za dogmat - definicja nie jest bynajmniej tak jednoznaczna i prosta, jak może sugerować powyższy lakoniczny cytat, albowiem już w roku $1909^{17}$ Freud podkreśla, że wyparcie w przypadku nerwicy natręctw posługuje się innym mechanizmem niż w pozostałych nerwicach przeniesieniowych (histerii lękowej i konwersyjnej) - to znaczy, traumatyczna treść nie ulega tutaj zapomnieniu (jak w histerii), lecz traci emocjonalny ładunek („obsadę afektu”) i zamienia się w neutralne, nieistotne dla świadomości wyobrażenie $^{18}$. Nie wchodząc w zawiłości związane z psychoanalityczną klasyfikacją chorób psychicznych, podkreślmy tylko, że ten pogląd (wsparty na doświad-

${ }^{15}$ Tenże, Wstęp do psychoanalizy, przeł. S. Kempnerówna, W. Znaniecki, Warszawa 2000, s. $273-274$.

${ }^{16}$ Tenże, Wyparcie..., s. 260.

${ }_{17}$ Z. Freud, Uwagi na temat pewnego przypadku nerwicy natręctw, przeł. R. Reszke, [w:] tenże, Charakter a erotyka, Warszawa 1996, s. 48 i nn.

18 Tamże, s. 49. 
czeniu klinicznym) stoi w jaskrawej sprzeczności z przytoczoną powyżej definicją wyparcia. Nie oznacza to bynajmniej, że Freud „tylko" modyfikuje czy odchodzi w artykule z 1915 roku od wcześniejszych ustaleń (z 1909), ponieważ podobne określenie sposobu funkcjonowania wyparcia pojawia się w pracy Zahamowanie, symptom, lęk (1926). Freud ponownie odróżnia tam nerwice natręctw od histerii i stwierdza, że w przypadku tych pierwszych patogenne formacje myślowe nie ulegają amnezji, „pozostają one świadome, ale w sposób, którego nie potrafimy sobie jeszcze wyobrazić [tzn. opisać, R. M.], zostają »izolowane «"19. W tekście z 1909 mowa jest o dwóch rodzajach wyparcia (histerycznego i nerwicowego) ${ }^{20}$, natomiast w pracy z 1926 pojawia się sugestia, że mechanizm wyparcia należałoby uznać za szczególną odmianę „szerszego” mechanizmu „odparcia” - czyli ogólnego określenia „wszystkich technik, którymi posługuje się "ja "w prowadzących ewentualnie do nerwicy konfliktach" ${ }^{21}$. Tekst nie precyzuje jednak, dla jakiego rodzaju nerwicy należałoby zarezerwować pojęcie wyparcia - linia wywodu autora nasuwa przypuszczenie, że najprawdopodobniej chodzi w tym przypadku o histerię. Jeśli tak, wówczas zniknęłaby wskazana przeze mnie sprzeczność między definicją z 1915 roku (wyparcie jako wykluczenie patogennego impulsu z obszaru świadomości) a definicją z 1909 (wyparcie pozbawia impuls energii emocjonalnej, ale nie odcina go od świadomości). Rozwiązanie tej sprzeczności polegałoby więc na czysto terminologicznej modyfikacji - wyparcie wywołujące amnezję zachodziłoby wyłącznie w przypadku histerii, natomiast kłopotliwa teoretycznie nerwica natręctw byłaby jedną z wielu form odparcia (1926). Nawet jeśli przyjmiemy taką interpretację, koncepcja wyparcia nadal będzie jednak zawierała wiele niejasności.

We Wstępie do psychoanalizy (1917) Freud, niepomny swojego wcześniejszego rozróżnienia dwóch odmiennych typów wyparcia, przypisuje wszystkim trzem rodzajom nerwicy przeniesieniowej (histerii lękowej, konwersyjnej oraz nerwicy natręctw) ten sam mechanizm wyparcia ${ }^{22}$, podobnie $w$ artykule Nieświadomość (1915), gdzie stwierdza, że odkrył wspólny dla nerwic przeniesieniowych mechanizm wyparcia: „Możemy teraz określić precyzyjnie, co wyparcie, w wypadku nerwic przeniesienia, uniemożliwia odrzuconemu wy-

\footnotetext{
${ }^{19}$ Z. Freud, Zahamowanie..., s. 264.

${ }^{20}$ Uwagi na temat, s. 49

${ }^{21}$ Z. Freud, Zahamowanie..., s. 264

${ }^{22}$ Tenże, Wstęp do psychoanalizy, s. 278-279.
} 
obrażeniu. Uniemożliwia mu ono przekład na słowa, które powinny zostać powiązane z obiektem"23.

Wprawdzie Freud opisuje tutaj pewne różnice w przebiegu procesu wyparcia, ale ostatecznie uznaje, że jego natura (uniemożliwienie „przekładu na słowa") pozostaje taka sama. Różnice dotyczą zasadniczo jedynie ilości energii zainwestowanej przez świadomość w tworzenie chorobowego symptomu. W histerii konwersyjnej symptom opiera się zarówno na energii popędowej, jak i na ładunku - przeciwstawnej wobec niej - energii świadomości, natomiast w nerwicy natręctw przewagę zdobywa hamujące dążenie systemu świadomości ${ }^{24}$.

Wskazana niejasność pojęcia Verdrängung oraz niekonsekwencja w posługiwaniu się nim, nie tylko utrudniają interpretację, ale również wydają się podważać spójność, a nawet sens całej teoretycznej konstrukcji psychoanalizy. Aby skonkretyzować ten zarzut, przyjrzyjmy się bliżej nowej formule wyparcia, jaką Freud przedstawia we wspomnianym artykule.

Dostępne świadomości wyobrażenia składają się, według niego, z dwóch elementów: wyobrażeń słownych oraz tak zwanych wyobrażeń rzeczowych (Sachvorstellungen), czyli mniej lub bardziej odległych śladów pamięciowych, które są nasycone emocjami i obsadzone ładunkiem energii popędowej. System nieświadomości zawiera tylko wyobrażenia rzeczowe oraz zawarte $\mathrm{w}$ nich dążenia popędowe. Wyparcie polega więc na oddzieleniu obydwu rodzajów wyobrażeń. Takie ujęcie implikuje jednak, że nie tylko wyparte treści, ale także opór przeciwko nim pozostaje nieświadomy, ponieważ systemy przedświadomości i świadomości z definicji funkcjonują na podłożu wtórnych, ujęzykowionych procesów mentalnych . Dlatego automatycznie nasuwa się w tym kontekście pytanie, co właściwie jest ową instancją, która nieświadomie wypiera patogenną treść? Z pewnością nie jest nią świadomość, która może, co najwyżej, odrzucić lub potępić jakieś wyobrażenie, utrzymując jednak potencjalny dostęp do niego - np. w postaci wspomnienia $^{25}$. W analizowanym artykule nie znajdziemy odpowiedzi na to pytanie, a co gorsza, kiedy sięgniemy do innych tekstów, otrzymamy odpowiedź, która popada w sprzeczność $\mathrm{z}$ naszkicowanym powyżej wywodem.

Na przykład w przywoływanym już artykule Wyparcie (również z 1915) czytamy o zjawisku odpychania, „które od strony świadomości oddziałuje na

\footnotetext{
${ }^{23}$ Tenże, Nieświadomość, przeł. M. Poręba, [w:] Z. Rosińska, Freud..., s. 223.

${ }^{24}$ Tamże, s. 210.

${ }^{25}$ Por. przyp. 9 i powiązany z nim komentarz w niniejszym artykule.
} 
to, co ma ulec stłumieniu”"26, a zatem Freud wyraźnie deklaruje tutaj, że świadomość ma swój udział w procesie odrzucenia czy zepchnięcia niechcianej myśli, obrazu, wspomnienia etc. do nieświadomości.

Niezależnie od tego, którą z interpretacji uznamy za słuszną (w zasadzie dysponujemy trzema wariantami - wyparcie może być realizowane przez: 1) jakąś bliżej nieokreśloną, nieświadomą instancję, 2) przez ego lub 3) częściowo przez świadomość i „nieświadome przyciąganie”), w każdym przypadku napotkamy nierozwiązywalne problemy i sprzeczności. Można je sprowadzić do następującego paradoksu: akt wyparcia w każdym z wymienionych wariantów zakłada pewną intencję skierowaną ku temu, co ma być wyparte, a zatem równocześnie zakłada jakąś formę obecności swojego obiektu. Zarówno w przypadku, gdy intencja ta jest nieświadoma, jak i wtedy, gdy jest świadoma (Freud nie precyzuje tej kwestii), akt wyparcia nie daje się jednak wytłumaczyć $\mathrm{w}$ ramach teorii psychoanalitycznej. W pierwszym przypadku (nieświadoma intencja) wyparcie miałoby bowiem całkowicie irracjonalny, przypadkowy charakter. Natomiast $\mathrm{w}$ drugim przypadku wyparcie nie byłoby po prostu możliwe, ponieważ akt świadomego „niechcenia czegoś” zachowuje potencjalny dostęp do tego, co niechciane (np. za pośrednictwem pamięci), a zatem z góry wyklucza możliwość „wykluczenia” zakazanego wyobrażenia z obszaru świadomości.

Freud był prawdopodobnie świadomy tych sprzeczności, jednakże obstawał przy ogólnych założeniach swojej koncepcji, ponieważ punktem wyjścia jego analiz były zawsze konkretne obserwacje kliniczne i w nich właśnie, a nie w logicznej spójności, odnajdywał „potwierdzenie” zasadności głoszonej przez siebie teorii. Doświadczenie, terapeutyczna praktyka dawała mu zatem zachętę do kontynuowania - i w razie potrzeby - do modyfikowania wcześniejszych ustaleń. Również w przypadku teorii wyparcia konflikt między logiczną niespójnością teorii a ewidencją doświadczenia zmusił go do wprowadzenia dodatkowego założenia w postaci „drugiej cenzury”.

W omawianym już tekście Nieświadomość dowiadujemy się, że topiczny model psychiki należy uzupełnić obserwacją, iż znaczny obszar przedświadomości pochodzi z nieświadomości, wypełniają go jej pochodne (Abkömmlinge), które poddawane są cenzurze i nie mogą zostać uświadomione. W tym miejscu pojawia się dodatkowe założenie.

${ }^{26}$ Z. Freud, Wyparcie..., s. 261. Por. również: tenże, Kilka uwag o pojęciu nieświadomości w psychoanalizie, przeł. R. Reszke, [w:] tenże, Psychologia nieświadomości, s. 20. 
Popadamy tu w sprzeczność $\mathrm{z}$ wcześniejszym założeniem. W rozważaniach nad wyparciem byliśmy zmuszeni do umieszczenia cenzury, decydującej o możliwości uświadomienia między systemami Nśw i Pśw. Teraz natomiast bliższe wydaje się istnienie cenzury pomiędzy Pśw a Św. Postąpimy chyba dobrze, nie upatrując w tej komplikacji żadnej trudności, lecz zakładając, że każdemu przejściu z jednego systemu do sąsiadującego z nim systemu wyższego, czyli każdemu postępowi ku wyższemu szczeblowi organizacji psychicznej, odpowiada nowa cenzura ${ }^{27}$.

Niestety, Freud niewiele pisze o sposobie funkcjonowania tej cenzury (między Pśw a Św), odwołuje się tylko do doświadczeń terapeutycznych i zauważa, że cenzura ta ma związek z procesami uwagowymi, a ściślej z określonymi ukierunkowaniami uwagi, które eliminują przedświadome pochodne nieświadomości. Ta niezwykle lakoniczna sugestia Freuda w zasadzie niczego nie wyjaśnia, możemy jedynie „wydedukować” jej sens na podstawie innych tekstów, w których poświęca on nieco więcej miejsca aktowi uwagi.

W Objaśnianiu marzeń sennych czytamy, że

[...] system pśw jest niczym ekran umieszczony pomiędzy systemem nśw a świadomością. System pśw nie tylko zamyka dostęp do świadomości - opanował on również dostęp do dowolnych ruchliwości, dysponuje on emitowaniem ruchliwej energii obsadowej, której część znana jest nam jako uwaga ${ }^{28}$.

Uwaga, w przeciwieństwie do procesu postrzegania, nie „wyczekuje” danych zmysłowych, lecz niejako wychodzi im naprzeciw, aktywnie poszukuje określonych treści (bodźców). Takie apetencyjne poszukiwanie bodźca potrzebuje jednak jakiegoś kryterium, „klucza”, w przeciwnym razie uwaga staje się bezcelowa i chaotyczna.

Aktywność ta [uwaga - uw. autora] zmierza w kierunku wrażeń zmysłowych, miast czekać, aż one same się pojawią. Prawdopodobnie równolegle ustanowiony został w ten sposób system zapamiętywania, którego działanie polega na na deponowaniu wyników tej periodycznej aktywności świadomej - część tego, co określamy mianem pamięci $i^{29}$.

\footnotetext{
${ }^{27}$ Tenże, Nieświadomość..., s. 215.

${ }^{28}$ Tenże, Objaśnianie marzeń sennych, przeł. R. Reszke, Warszawa 1996, s. 514.

${ }^{29}$ Tenże, Uwagi na temat dwóch zasad procesu psychicznego, przeł. R. Reszke, [w:] tenże, Psychologia nieświadomości, s. 9.
} 
Odnosząc te ustalenia do poglądu Freuda, że wyparcie zachodzi w systemie $p s ́ w$, natrafiamy na podobne problemy, które wskazaliśmy powyżej. Założenie, że wypierająca instancja cenzury ulokowana jest w przedświadomości i opiera się na uwadze oraz pamięci, jest wewnętrznie sprzeczne. Samocenzurująca się przedświadomość odrzuca tutaj bowiem wyobrażenia, które musiały być już przez nią uświadomione (za pomocą uwagi i pamięci), co uniemożliwia będące warunkiem wyparcia całkowite odizolowanie wyobrażenia od świadomości. Ponadto wysoce problematyczny wydaje się pomysł usytuowania cenzur między systemami psychicznymi.

Freud często porównuje cenzurę do „strażnika”, który obserwuje, sprawdza treści psychiczne pod kątem ich zgodności z wymogami krytycznego rozumu: „Los stłumienia (Verdrängung) pojedynczego dążenia polega na tym, że nie zostaje ono wpuszczone przez strażnika z systemu nieświadomego do systemu przedświadomego. Jest to ten sam strażnik, którego poznajemy jako opór, gdy chcemy usunąć stłumienie przez leczenie analityczne" ${ }^{\prime 30}$. Antropomorfizacja cenzury jako strażnika ilustruje - wbrew intencji Freuda - jej niemożliwość na gruncie założeń psychoanalizy, ponieważ zakłada akt świadomego wyparcia, a - jak pamiętamy - wyparcie musi mieć charakter nieświadomy. Zarówno sugerowane tutaj „racjonalne”, jak i inne „treściowe” kryteria odrzucania ocenzurowanych wyobrażeń, które omówimy w dalszej części artykułu ${ }^{31}$, zakładają pewien rodzaj wiedzy - wiedzy, która, według Freuda, nie powinna być uświadamiana, jeśli proces wyparcia ma się powieść. Aby rozpoznać „niebezpieczną” pochodną nieświadomości i móc ją następnie odrzucić, instancja wypierająca potrzebuje mniej lub bardziej wyraźnej znajomości „oryginału”.

Jeśli jednak wrócimy jeszcze do poglądu przeciwnego, to stwierdzimy, że nie jest w nim słuszne nawet to, iż wyparcie izoluje od świadomości wszystkie pochodne elementy wyparcia pierwotnego. Jeżeli wskutek odkształceń czy też w rezultacie licznych członów pośrednich są one dość znacznie oddalone od wypartej reprezentacji popędu, to ich dostęp do świadomości jest zupełnie swobodny. Jest tak, jak gdyby opór świadomości przed nimi był funkcją ich oddalenia od przedmiotu wyparcia pierwotnego ${ }^{32}$.

\footnotetext{
${ }^{30}$ Tenże, Wstęp do psychoanalizy, s. 276.

${ }^{31} \mathrm{~W} 11$ rozdziale Psychologii zbiorowości Freud utożsamia krytyczną instancję z „ideałem Ja”, a w 3 rozdziale rozprawy Ego i id - z „Nad-Ja”.

32 Tenże, Wyparcie..., s. 262.
} 
Wyposażenie cenzury w treściowe kryteria identyfikacji i odrzucania niewygodnych wyobrażeń implikuje jednak nie tylko opisany powyżej paradoks, ale również nieskończony regres następujących po sobie cenzur ${ }^{33}$. Ten ostatni wspomniany tu problem omówimy w następnym rozdziale.

\section{Wyparcie w perspektywie „ekonomicznej”}

W poprzednim punkcie pokazaliśmy paradoksy freudowskiej teorii wyparcia, wynikające z przyjętego przez niego poglądu, że dostęp do świadomości wzbroniony jest nie tylko wypartej treści, ale również wypierającej instancji. W Ego i id (1923) Freud stwierdza, że główną instancją wypierającą jest Ja, a ściślej przejawiające się w nim nieświadome opory. „Ego to jest źródłem wyparć, których zadaniem jest nie tylko wykluczenie ze świadomości pewnych dążeń psychicznych, lecz także uniemożliwienie im innych rodzajów manifestacji i aktywności”34. Dalej w tekście dowiadujemy się, że w samym ego znajdują się oderwane odeń treści wyparte, które wchodzą z nim w konflikt. Ta modyfikacja dawnego modelu topicznego łączy się zarazem z nowym ustaleniem, że niecała nieświadomość pochodzi z wyparcia ${ }^{35}$. Okazuje się ponadto, że w samej nieświadomości daje się zaobserwować wyraźne dążenie do uświadomienia. Freud wspomina o tym już w artykule Wyparcie (1915): „Możemy sobie wyobrazić, że to, co wyparte, stale wywiera presję w kierunku świadomości, a za sprawą wywieranej przez nią presji przeciwnie ukierunkowanej zachowywana jest równowaga” ${ }^{36}$. Wskazana tutaj „przeciwnie ukierunkowana presja” nie przekracza progu uświadomienia i jest tożsama

\footnotetext{
${ }^{33}$ Wydaje się, że Freud uzmysławiał sobie wpisane w teorię wyparcia ryzyko mnożenia w nieskończoność cenzur, a także cenzurujących oporów przeciwko próbom ujawnienia oporów. Por. Z. Freud, Analiza skończona i nieskończona, przeł. J. Prokopiuk, [w:] tenże, Poza zasada przyjemności..., s. 177.

${ }^{34}$ Tenże, Ego i id..., s. 299.

${ }^{35}$ Stwierdzenie, że niecała nieświadomość pochodzi z wyparcia, pada na pierwszej stronie artykułu Nieświadomość, niestety Freud nie precyzuje, jaki inny mechanizm „produkuje” nieświadomość. W artykule mowa jest o utajonych procesach psychicznych. Pojawia się też sugestia, że w nieświadomości znajdują się treści nienabyte przez jednostkę, a zatem poniekąd mające charakter filogenetyczny (aluzja do archetypów Junga?). Uwagi o „reliktach” filogenetycznych „wspomnień” wypełniających nieświadomość, a zatem niebędących rezultatem wyparcia, można znaleźć również w Objaśnianiu marzeń sennych.

${ }^{36}$ Z. Freud, Wyparcie, przeł. R. Reszke, [w:] tenże, Psychologia nieświadomości, s. 83.
} 
z tym, co Freud określa mianem oporu. Obserwacja tego fenomenu skłoniła go do przeformułowania teorii psychicznego aparatu - dawny topiczny model (świadome-przedświadome-nieświadome) został tutaj zastąpiony strukturalnym podziałem na ego (Ja), id (To) oraz superego (Nad-Ja). Id porównywane do „kotła, w którym kipią bodźce popędowe” 37 jest całkowicie irracjonalne, nie zna negacji (dlatego nie może być źródłem oporu!) ani moralnych wartościowań, funkcjonuje poza chronologią czasową, która organizuje świadome przeżycia. Jednakże nieświadome aspekty Ja odróżniają się od chaotycznej, alogicznej natury Tego racjonalną tendencją do organizowania, porządkowania reprezentacji popędowych: „Tym, co stanowi bardzo szczególny wyróżnik »ja " w stosunku do »tego «, jest dążenie do syntetyzowania treści wchodzących w skład »tego«, do zespolenia i ujednolicenia zachodzących w nim procesów psychicznych"38. Ego jako instancja wypierająca pozbawione jest zatem irracjonalnego charakteru $i d$. W kontekście naszych wywodów istotne znaczenie ma przy tym również to, że opór stawiany przez świadome i przedświadome Ja podlega zasadzie rozkoszy ${ }^{39}$, a zatem jego celem jest uniknięcie za wszelką cenę nieprzyjemnych przeżyć, które mogłyby wywołać wyparte treści ${ }^{40}$. Podłożem oporu Ja jest „praca myśli” (która może przebiegać poniżej progu świadomości) opóźniająca bezpośrednie zaspokojenie impulsu popędowego ${ }^{41}$. Procesem myślowym, który odpowiada za odrzucanie niebezpiecznych roszczeń popędowych, rządzi wzgląd na bezpieczeństwo ${ }^{42}$, a zatem $\mathrm{w}$ ramach procesu wypierania dochodzi do współdziałania zasady przyjemności (opór) z zasadą rzeczywistości (praca myśli). Napotykamy tutaj tę samą sprzeczność, co wcześniej - z jednej strony wyparcie wymaga pewnej wiedzy o tym, co ma być wyparte, a z drugiej strony sam opór (czyli właściwa

\footnotetext{
${ }^{37}$ Por. opis funkcjonowania id w: Z. Freud, Wykłady ze wstępu do psychoanalizy. Nowy cykl, przeł. P. Dybel, Warszawa 1995, s. 85 i nn.

${ }^{38}$ Tamże, s. 88.

${ }^{39}$ Według Freuda opór Ja pochodzi z jego nieświadomej części (tzw. wewnętrznej zagranicy), która podporządkowana jest zasadzie rozkoszy. Zasada ta obiera dwa kierunki: dążenie do rozkoszy i do unikania braku rozkoszy. Wspomniany „opór” nie dąży oczywiście do rozkoszy, tylko do uniknięcia braku rozkoszy.

${ }^{40}$ Por. Z. Freud, Poza zasadą rozkoszy, przeł. R. Reszke, [w:] tenże, Psychologia nieświadomości, s. $174-175$.

${ }^{41}$ Por. tenże, Wykłady ze wstępu do psychoanalizy..., s. 88-89.

${ }^{42}$ Tenże, Zarys psychoanalizy, przeł. J. Prokopiuk, [w:] tenże, Poza zasada przyjemności..., s. $148-149$.
} 
cenzura) zachodzi nieświadomie: „Otóż opory te, jakkolwiek należą do ego, są jednak nieświadome i w pewnym sensie wyodrębnione wewnątrz ego" ${ }^{33}$.

Wyodrębniony w obszarze Ja opór jest zatem bezwiedny i kieruje się bezpośrednio przeciwko wypartym treściom, które reprezentuje symptom. „Symptom pochodzi od tego, co wyparte, znajduje się poza obszarem »ja«, jest jego wewnętrzną zagranicą" ${ }^{44}$. Freud stwierdza przy tym, że opór stanowi ekspresję Nad-Ja, które wcześniej dokonało wyparcia (lub „zleciło” jego dokonanie instancji Ja $)^{45}$. Co zaskakujące - a dla nas znamienne - twórca psychoanalizy przyznaje, że nie potrafi wskazać przyczyn konieczności przebiegającego nieświadomie oporu (i wyparcia). W pracy Ego i id znajdujemy jednak próbę wyjaśnienia tego zjawiska:

Otóż ze względu na znaczenie, które przypisaliśmy przedświadomym reliktom słownym istniejącym $\mathrm{w}$ ego, powstaje pytanie, czy superego, jeśli jest nśw, nie składa sie z tego rodzaju wyobrażeń słownych lub czegoś podobnego. Skromna odpowiedź brzmi: superego nie może również zaprzeczyć swemu pochodzeniu z tego, co zostało zasłyszane, jest ono przecież częścią ego i dzięki tym wyobrażeniom słownym (pojęciom, abstrakcjom) jest dostępne świadomości, jednakże te treści superego nie otrzymują energii obsadzenia (kateksji) z postrzeżeń słuchowych, nauki czy lektury, lecz ze źródeł znajdujących się w $i d^{46}$.

Superego jako instancja wypierająca i źródło oporu nie jest zatem ustrukturyzowane według zasad rządzących procesem pierwotnym, czyli zgodnie z prawami zagęszczenia (Verdichtung) i przemieszczenia (Verschiebung) wyobrażeń rzeczowych (Sachvorstellungen), lecz według reguł językowych, które organizują obecne w niej wyobrażenia słowne, dlatego też jest dostępne świadomości. W tym sensie Nad-Ja ma charakter przedświadomy, ale rodzący się w nim opór (i poprzedzające go wyparcie) pozostają nieświadome. Tę sprzeczność ma tłumaczyć fakt, że energia zasilająca wyobrażenia słowne nie pochodzi $\mathrm{w}$ tym przypadku z świadomej percepcji, lecz z nieświadomych pokładów id. Nasuwa się jednak pytanie, jak i czy w ogóle możliwe jest tego rodzaju powiązanie swobodnej energii, która $\mathrm{z}$ natury nie kieruje się żadnymi kryteriami moralnymi, z oceniającą funkcją ujęzykowionego

\footnotetext{
${ }^{43}$ Por. tenże, Analiza skończona..., s. 177.

${ }^{44}$ Por. tenże, Wykłady ze wstępu do psychoanalizy..., s. 67.

${ }^{45}$ Tamże, s. 80.

${ }^{46}$ Z. Freud, Ego i id..., s. 328-329.
} 
Nad-Ja? Freud próbuje to wyjaśnić, wskazując - za Nietzschem ${ }^{47}$ - że część potencjalnie destrukcyjnej energii niewykorzystanej przez ego zostaje przekształcona w superego obarczające wyrzutami sumienia ${ }^{48}$. Impuls popędowy przeniesiony z systemu id do superego przechodzi zarazem na „wyższy” poziom energetyczny, na którym dochodzi do „związania” swobodnie dotąd przepływającej energii za pośrednictwem struktur językowych ${ }^{49}$. Uzyskana dzięki temu nadwyżka energii ma służyć do obsadzenia antagonistycznych procesów psychicznych, a tym samym umożliwia realizację aktu wyparcia. To skromne - jak zauważa Freud - wyjaśnienie nie pomaga jednak rozwiązać problemu wynikającego z konieczności przyjęcia istnienia dodatkowej cenzury w obrębie Nad-Ja. Według zarysowanej tutaj nowej teorii wyparcia, superego komunikuje się $\mathrm{z}$ id na płaszczyźnie energetycznej ${ }^{50}$, a zatem bezpośrednio konfrontuje się z niebezpiecznymi impulsami, jednak stawia im opór, ponieważ funkcjonuje zarazem jako przedświadomy, „karzący” system psychiczny, powstały w rezultacie introjekcji zewnętrznych zakazów. W tym sensie ego nie jest świadome oporów Nad-Ja, a niekiedy na jego zlecenie samo stawia opór niebezpiecznym impulsom, nie znając jednak jego rzeczywistych powodów.

Powyższa konstrukcja teoretyczna nie jest bynajmniej ani jasna, ani przekonująca na gruncie samej psychoanalizy. Po pierwsze, Freud zakłada, że superego jako „wewnętrzna zagranica" ${ }^{51} \mathrm{w}$ obrębie Ja powstało w wyniku wyparcia (musiało zostać wyparte, ponieważ jest „zanurzone” w nieświado-

${ }^{47}$ F. Nietzsche, Z genealogii moralności. Pismo polemiczne, przeł. L. Staff, Kraków-Warszawa 1906, s. 92-94.

${ }^{48}$ Z. Freud, Kultura jako źródło cierpień, przeł. R. Reszke, Warszawa 1995, s. 72.

${ }^{49}$ Termin „wiązanie” stanowi jedno z wielu metaforycznych, niejednoznacznych pojęć, za pomocą których Freud opisuje procesy wtórne. Ogólnie rzecz ujmując, polega ono na zahamowaniu procesów pierwotnych i utrwaleniu płynnych wyobrażeń w określonej, stałej formie. Język składa się z wyobrażeń słownych, które łączą się ze sobą zgodnie z regułami gramatyki i na których opierają się procesy myślowe. W tym sensie struktury językowe (tzn. wyobrażenia słowne oraz ustalone „odgórnie” przez gramatykę relacje między nimi) wiążą, tj. „nadają formę" energii psychicznej. Więcej na ten temat w przygotowywanym przeze mnie artykule: Problem pochodzenia języka w świetle klasycznej antropologii. Stanowiska Johanna Gottfrieda Herdera, Arnolda Gehlena, Zygmunta Freuda.

${ }^{50}$ „Bogate kontakty owego ideału z tymi nśw popędami rozwiążą zagadkę tego, że ideał, sam w znacznej mierze nieświadomy, może pozostać niedostępny dla ego. Walka, która toczyła się w głębszych warstwach psychiki i nie została zakończona wskutek szybkiej sublimacji i identyfikacji, teraz - niby bitwa z Hunami na obrazie Kaulbacha - kontynuowana jest w wyższych regionach", w: Z. Freud, Ego i id..., s. 317.

${ }^{51}$ Por. przyp. 36. 
mości), nie potrafi jednak wyjaśnić, jak do niego doszło. W istocie, zamiast rozwiązać ten problem na płaszczyźnie teoretycznej, kieruje się ku terapeutycznej empirii, która dostarcza mu wielu przykładów symptomów chorobowych, będących bezpośrednim efektem wyparcia oraz bazującego na nim oporu. Doświadczenie kliniczne skłania go ponadto do przyjęcia poglądu, że akt wyparcia oraz opór są nieświadome, a więc niedostępne dla ego. Pogląd ten stoi jednak w sprzeczności $z$ fundamentalnym założeniem psychoanalizy, że aktu wyparcia dokonać może wyłącznie ego. Aby wytłumaczyć zaistniałą sprzeczność, Freud postuluje dodatkową instancję wypierającą, zlokalizowaną tym razem w Nad-Ja. Takie rozwiązanie okazuje się pozorne, ponieważ superego jako instancja wypierająca zakłada inną instancję wypierającą, mianowicie Ja. Innymi słowy, aby wyjaśnić paradoks nieświadomej „wiedzy”, jaką musi dysponować ego w trakcie wyparcia, Freud postuluje istnienie innej instancji wypierającej. To zaś naraża go nieuchronnie na ryzyko popadnięcia w nieskończony regres - nie ma bowiem w zaproponowanej przez niego argumentacji żadnych teoretycznych racji, żadnej logicznej konieczności, która mogłaby powstrzymać go przed wysunięciem postulatu kolejnych wypierających instancji.

Przyjrzyjmy się teraz, w jaki sposób prezentuje się wskazany paradoks teorii wyparcia w perspektywie „ekonomicznego” (uwzględniającego energetyczny aspekt mentalnych procesów) opisu ludzkiej psychiki.

Spostrzegliście na pewno, że w ostatnich wyjaśnieniach włączyłem w ogniwa łańcucha etiologicznego nowy czynnik, a mianowicie ilość, wielkość energii wchodzącej w rachubę. [...] Często jakościowa analiza warunków etiologicznych nie wystarczy. Lub też, by to wyrazić inaczej, czysto dynamiczne ujęcie tych procesów duchowych jest niewystarczające, wymaga ono jeszcze ekonomicznego punktu widzenia. Musimy sobie powiedzieć, że konflikt między dwoma dążeniami nie wybucha, póki nie zostaje osiągnięta pewna intensywność obsadzenia, chociażby nawet warunki treściowe dawno istniały ${ }^{52}$.

Dopóki zatem skonfliktowane dążenia psychiczne nie przekraczają pewnego progu natężenia energetycznego, nie mają żadnego znaczenia dla działającego podmiotu. Dopiero podwyższenie „intensywności obsadzenia” konkurujących ze sobą o pole ekspresji wyobrażeń czyni niezbędnym zahamowanie procesu „odprowadzania” energii w postaci działania.

${ }^{52}$ Z. Freud, Wstęp do psychoanalizy, s. 339-340. 
Akt zaniechania podjęcia czynności na podłożu aktualnego konfliktu popędowego możemy zilustrować na przykładzie poczucia winy. Freud wyróżnia dwa jego źródła: lęk przed zewnętrznym autorytetem oraz późniejszy (w perspektywie onto- i filogenetycznej) lęk przed Nad-Ja ${ }^{53}$. W drugim przypadku wyrzeczenie się popędów jest niewystarczające, gdyż zakazane pragnienie nie daje się ukryć przed superego, które kieruje agresję (wynikający z poczucia winy przymus „karania”) przeciwko Ja nawet wówczas, gdy „złe” działanie nie doszło do skutku. Agresja skierowana jest w tym przypadku, jak przypuszcza Freud, pierwotnie ku osobie czy instytucji, która uniemożliwia seksualne zaspokojenie.

W toku pracy analitycznej dowiedzieliśmy się jednak, ku naszemu zaskoczeniu, że być może za każdą nerwicą kryje się pewna doza nieświadomego poczucia winy, ta zaś wzmacnia te symptomy, stosując je jako karę. Blisko stąd do następującego stwierdzenia: jeśli dążenie popędowe ulega wyparciu, to jego składniki libidalne przekształcone zostają w symptomy, a jego komponenty agresywne w poczucie winy ${ }^{54}$.

Jednakże wyparcie, rozumiane tutaj jako strategia rozwiązywania konfliktów popędowych, nie tylko blokuje impuls do działania, ale również musi wygasić świadomą intencję. Freud wyraźnie odróżnia obydwa rodzaje wyparcia, które pociągają za sobą różne „losy” wypartych treści. Z jednej strony wyparciu ulega zatem reprezentacja popędu, jaką stanowi wyobrażenie lub grupa wyobrażeń wyposażona w określoną dozę energii psychicznej, z drugiej zaś strony, niejako oddzielnie, wypierany jest element reprezentacji popędu określany przez Freuda mianem "potencjału afektu” (Affektbetrag), który odpowiada energii popędowej oddzielonej od wyobrażenia i przejawiającej się w postaci tak zwanych afektów doznawania (Affekte der Empfindung) ${ }^{55}$. Ostatni wariant został zmodyfikowany przez Freuda w pracy Zahamowanie, symptom, lęk, z której dowiadujemy się, że źródłem lęku nie jest energia libidalna (jak wcześniej utrzymywała Freud), lecz instancja wypierającego Ja ${ }^{56}$. Sygnał lękowy odbierany przez ego jako ostrzeżenie przed niebezpiecznym impulsem popędowym uruchamia proces wyparcia. Ja poddaje się $\mathrm{w}$ tym przypadku lękowi „niczym szczepieniu, aby za sprawą osłabionego wybuchu

\footnotetext{
${ }^{53}$ Por. tenże, Kultura jako źródło cierpień, s. 76-78.

${ }^{54}$ Tamże, s. 88.

${ }_{55}$ Por. Z. Freud, Wyparcie, przeł. R. Reszke, [w:] tenże, Psychologia nieświadomości, s. 84.

${ }^{56}$ Tenże, Zahamowanie..., s. 219.
} 
choroby uniknąć ataku choroby w formie niczym nie osłabionej" ${ }^{57}$. Wzorcem tego mechanizmu obronnego ${ }^{58}$ jest dla Freuda lęk odczuwany w chwili narodzin jako reakcja dziecka na traumatyczną sytuację bezradności ${ }^{59}$. Wprawdzie lęk odróżnia się od strachu czy obawy swoją bezprzedmiotowością i nieokreślonością, jednak „W sposób niewątpliwy odnosi się do oczekiwania; jeśli lęk się pojawia, to jest to lęk przed czymś" ${ }^{60}$. Oczekiwanie pojawia się wówczas, gdy jakaś sytuacja (zawierająca sygnał lęku) przypomina jedno $\mathrm{z}$ wcześniejszych traumatycznych przeżyć bezradności. Ja zaczyna się wówczas zachowywać tak, jakby faktycznie miało do czynienia z zagrożeniem, a zatem niejako powtarza - w złagodzonej postaci - traumę ${ }^{61}$. Ustalenie to implikuje zatem, że osądzające Ja w akcie wyparcia nie daje się zredukować do czynnika czysto energetycznego (odrzucenie nieokreślonego afektu), lecz zakłada określone, „jakościowe” wyobrażenia. W tym miejscu ponownie pojawia się problem dotyczący tego, jak i czy w ogóle da się w przyjętych ramach teoretycznych wyjaśnić nieświadomy status „wypierającej” oceny ego. Aby rozwiązać tę trudność, Freud próbuje pokazać, że osąd leżący u podłoża aktu wyparcia może "zidentyfikować" niebezpieczną sytuację, nie opierając się na jakościowych kryteriach. Taka możliwość zachodzi, jego zdaniem, w chwili narodzin: „Niebezpieczeństwo narodzin nie ma jeszcze żadnej treści psychicznej. W wypadku płodu nie możemy rzecz jasna zakładać niczego, co byłoby zbliżone do wiedzy na temat możliwości pojawienia się rezultatu odpowiadającego unicestwieniu życia" ${ }^{2}$. Kluczowym elementem stanu, w którym noworodek odczuwa lęk - będący wzorcem dla późniejszych aktów wyparcia - jest narastanie napięcia wywołanego przez domagającą się bezpośredniego zaspokojenia potrzebę:

Sytuacja niezaspokojenia, w której wielkości pobudzenia wzbijają się na same wyżyny braku rozkoszy, sytuacja nieuregulowana jakąś formą wykorzystania i odprowadzenia psychicznego, musi być dla noworodka analogiczna z przeżyciem narodzin, musi być dlań przeżyciem narodzin, musi być dlań powtórzeniem sytuacji zagrożenia; i dla jednej, i dla drugiej sytuacji wspólną cechą

\footnotetext{
57 Tamże, s. 263.

${ }^{58}$ Więcej na temat mechanizmów obronnych w: J. Laplanche, J. B. Pontalis, Słownik psychoanalizy, s. 135-137.

${ }^{59}$ Id nie odczuwa lęku ani nie jest w stanie ocenić sytuacji zagrożenia, por. tamże, s. 243.

${ }^{60}$ Tamże, s. 265.

${ }^{61}$ Tamże, s. 266.

${ }^{62}$ Tamże, s. 239.
} 
jest jest zburzenie ekonomii libido poprzez przyrost domagających się zlikwidowania wielkości pobudzenia, a zatem czynnik ten jest właściwym rdzeniem niebezpieczeństwa ${ }^{63}$.

Ilościowy wzrost pobudzenia niejako automatycznie pociąga za sobą wyparcie indukowane przez powstały $\mathrm{w}$ ten sposób lęk $\mathrm{k}^{64}$. Wyparcie odbywa się zatem w tym przypadku wyłącznie na podstawie ilościowego kryterium. Freud konkretyzuję tę ideę w jednym $\mathrm{z}$ ostatnich wykładów ${ }^{65}$, gdzie stwierdza wyraźnie, że traumatyczne przeżycie (a zatem paraliż zasady rozkoszy) pojawia się, gdy przekroczony zostaje pewien próg intensywności pobudzenia, a zatem nie jest wywołane przez konkretne wyobrażenia czy percepcje (czynnik jakościowy). Precyzuje przy tym, że wskazany mechanizm funkcjonuje głównie we wczesnej fazie rozwoju ontogenetycznego: „pierwsze i pierwotne wyparcia powstają bezpośrednio w trakcie konfrontacji "Ja" z nadmiernymi roszczeniami libido złożonymi z czynników traumatycznych, tworzą one swój lęk na nowo, lecz zgodnie z pierwowzorem lęku narodzin"66. Źródłem późniejszych wyparć nie jest już bezpośrednia obecność czynnika traumatycznego, lecz sygnał lękowy, który przypomina (za pośrednictwem określonego wyobrażenia) wcześniejszą sytuację zagrożenia. Wyparcie chroni w obydwu przypadkach organizację Ja, a zatem i wspierający ją proces wtórny (myślenie oparte na strukturach językowych), przed „powrotem” do stanu, którym rządzi proces pierwotny (swobodny przepływ „niezwiązanej” energii psychicznej) ${ }^{67}$.

Przedstawiona powyżej propozycja rozwiązania paradoksu nieświadomego wyparcia treści popędowych przez świadome ego nie wydaje się jednak przekonująca. Najważniejsza wątpliwość dotyczy zasadności samego rozróżnienia - skądinąd fundamentalnego dla psychoanalizy - między procesem wtórnym i pierwotnym. Nie wchodząc w szczegóły tej problematyki, zauważmy tylko, że założenie istnienia niezwiązanej energii popędowej (cecha wy-

63 Tamże, s. 241.

${ }^{64}$ Tamże, s. 243.

${ }^{65} \mathrm{~W}$ tym punkcie argumentacji łączę ustalenia Freuda pochodzące z dwóch oddalonych czasowo tekstów (1900 i 1933). Wprawdzie przez ten czas Freud zmodyfikował swoją teorię $\mathrm{w}$ wielu aspektach, jednakże $\mathrm{w}$ odniesieniu do omawianej tutaj problematyki wczesnego wyparcia autor Wykładów $z$ wstępu do psychoanalizy nie wprowadził żadnych zmian, tylko skonkretyzował i doprecyzował (jak zaznaczam w tekście) ideę, że wczesne formy wyparcia wywołane lękiem powstają zgodnie z pierwowzorem lęku narodzin.

${ }^{66}$ Z. Freud, Wykłady ze wstępu do psychoanalizy..., s. 108.

${ }^{67}$ Por. tenże, Objaśnianie marzeń sennych, s. 504. 
partej treści) neguje możliwość przeprowadzenia jakiejkolwiek skutecznej terapii. Jeśli zakazane impulsy nie wiążą się na stałe z żadnym wyobrażeniem, żadnym słowem czy percepcją, to w istocie nie sposób sobie wyobrazić, jak można byłoby je przechwycić, terapeutycznie „przepracować” i doprowadzić do stanu uświadomienia. Zabiegi terapeuty przypominałyby wówczas chaotyczne, zdane na przypadek rytuały szamana, który może liczyć jedynie na „cud” lub szczęśliwy zbieg okoliczności. Ponadto nierozwiązana pozostaje w tej argumentacji kwestia wyparcia świadomych lub przedświadomych (a zatem „związanych”) wyobrażeń.

\section{Wyparcie a język w kontekście podziału na pierwotny i wtórny proces psychiczny}

W Objaśnianiu marzeń sennych Freud przedstawia hipotezę pierwotnego aparatu psychicznego, który powstaje na bazie systemu motorycznego.

Hipotezy, które należy uzasadnić w inny sposób, powiadają nam, że ten aparat zrazu podążał za usiłowaniem polegającym na tym, by utrzymać się w stanie możliwie wolnym od bodźców, przeto przejął on do swej pierwszej struktury schemat aparatu odruchowego, dzięki czemu mógł od razu motorycznie odprowadzić docierającą doń podnietę zmysłową ${ }^{68}$.

Przejście od funkcji odruchowej do czynności psychicznej następuje na skutek wystąpienia niedostatku, silnych i niezaspokojonych potrzeb cielesnych. Bezradne dziecko bezskutecznie próbuje rozładować powstające $\mathrm{w}$ organizmie napięcie i dopiero pomoc udzielona $\mathrm{z}$ zewnątrz pozwala mu zaspokoić potrzebę. Freud wysuwa przy tej okazji hipotezę, że pierwotny proces psychiczny konstytuuje się $\mathrm{w}$ momencie, gdy zostaje przełamana presja czynności odruchowych, a ściślej w momencie narodzin pragnienia/życzenia (der Wunsch) ${ }^{69}$. Życzenie powstaje mianowicie na podłożu syntezy (asocjacji) dwóch przedstawień $\mathrm{w}$ systemie pamięciowym: obrazu pamięciowego pierwotnego zaspokojenia oraz śladu pamięciowego pobudzenia wywołane-

\footnotetext{
${ }^{68}$ Tamże, s. 476.

${ }^{69}$ Wychodząc od tej hipotezy, Lacan wypracował swoją słynną koncepcję pragnienia. Por. J. Laplanche, J. B. Pontalis, Słownik psychoanalizy, s. 242-243.
} 
go potrzebą ${ }^{70}$. Kształtujący się w ten sposób aparat psychiczny dąży do halucynacyjnego odtworzenia zaspokojenia, dzięki czemu udaje mu się częściowo zneutralizować napięcie i przetrwać do chwili realnej gratyfikacji. Pragnienie uznane za pierwszą aktywność psychiczną stanowi integralny składnik „pierwotnego procesu", który jest nastawiony na unikanie przykrości i dążenie do rozkoszy, a w ostatecznym rezultacie dąży do halucynacyjnego odtworzenia wcześniejszych zaspokojeń. Freud, opisując powstawanie i dynamikę pragnienia, przyjmuje, że tworzy ono niedostępny dla świadomości, ale niezwykle trwały i stabilny obszar pierwotnych fantazji - „rdzeń naszej natury”11 podskórnie determinujący procesy psychiczne (w tym myślenie pojęciowe). Pragnienie budzi świadomość, ale jednocześnie, z powodu swojej orientacji na iluzoryczne obiekty, zakłóca doświadczenie zewnętrznej rzeczywistości. Jednostka musi je wyprzeć, aby móc funkcjonować w społeczeństwie kierującym się zasadą rzeczywistości.

Pragnienie obsadza energią popędową obraz pamięciowy zaspokojenia, chcąc ponownie je wywołać, a tym samym dąży do wytworzenia identyczności postrzeżeniowej (Wahrnehmungsidentität) z tym przeżyciem ${ }^{72}$, dąży zatem do halucynacyjnego utrwalenia upragnionego obiektu (a ściślej - sta$\mathrm{nu}$ ). Freud próbuje w tym kontekście (funkcjonowania procesu pierwotnego) usytuować również akt wyparcia, jednak jego uwagi na ten temat są bardzo lakoniczne. Dowiadujemy się bowiem, że wspomnienia, od których wywodzi się nieświadome życzenie, nigdy nie mogą być dostępne dla świadomości/ przedświadomości, a ponieważ zawarta $\mathrm{w}$ nich energia dąży z natury do odprowadzenia motorycznego (w działaniu czy zaspokojeniu), po przekroczeniu określonego progu intensywności niejako automatycznie przechodzi na pewne przedświadome myśli (wyobrażenia), zakazane pragnienie próbuje za ich pośrednictwem osiągnąć swój cel, co z kolei rodzi tak zwaną obsadę przeciwną (Gegenbesetzung) ze strony przedświadomości ${ }^{73}$.

Wyparcie jest tutaj zatem dziełem przedświadomości, która jednak nie kieruje się bezpośrednio przeciwko zakazanym, nieświadomym myślom, lecz przeciwko pewnym wyobrażeniom zastępczym, tak zwanym myślom przeniesieniowym. W efekcie konfliktu różnie ukierunkowanych „strumieni” energii psychicznej wyobrażenie przeniesieniowe może przekształcić się

\footnotetext{
${ }^{70}$ Z. Freud, Objaśnianie marzeń sennych, s. 476.

${ }^{71}$ Tamże, s. 505.

72 Tamże, s. 504.

${ }^{73}$ Tamże, s. 506.
} 
w symptom chorobowy. Freud nie wyjaśnia jednak, według jakich kryteriów zostaje dokonany „wybór” takiego, a nie innego wyobrażenia do „roli” reprezentanta ukrytego życzenia, tzn. nie dowiadujemy się, czy chodzi tutaj o kryteria ilościowe (czysto energetyczne) - jeśli tak, to powyższy wybór miałby zasadniczo charakter przypadkowy, czy też w grę wchodzą jakieś inne kryteria jakościowe, czyli związane z konkretnymi własnościami samych wyobrażeń.

Wyjaśnienie to, jak widać, prowokuje kolejne pytania i wątpliwości, zamiast doprowadzić nas do rozwiązania paradoksu wyparcia. Żeby rzucić nieco więcej światła na te wstępne intuicje Freuda, przyjrzyjmy się problematyce Verdrängung w kontekście analizy histerii lękowej, chociaż musimy przyznać - uprzedzając dalsze ustalenia - że również w tym przypadku argumentacja twórcy psychoanalizy pozostawia wiele do życzenia.

W artykule Nieświadomość, do którego już wielokrotnie się odwoływaliśmy, Freud opisuje dwie fazy wyparcia zakazanej pobudki miłosnej. W pierwszej fazie nieświadoma energia wycofuje się, „jak gdyby podejmując próbę ucieczki”" ${ }^{\prime 4}$ z wyobrażenia na skutek oddziaływania obsady przedświadomej, a następnie przekształca się w bezprzedmiotowy lęk. W drugiej fazie, czyli wówczas, gdy cały proces powtarza się, „uciekająca” nieświadoma obsada zwraca się w stronę wyobrażenia zastępczego, „które z jednej strony wiązane było skojarzeniowo z odrzuconym wyobrażeniem, $\mathrm{z}$ drugiej zaś za sprawą oddalenia od niego nie podlegało wyparciu (zastępstwo przesunięcia), pozwalając na dokonanie racjonalizacji niemożliwego jeszcze do zahamowania rozwoju lęku"75. Zgodnie z tym nowym ustaleniem (a właściwie uzupełnieniem ujęcia $z$ Traumdeutung) proces tworzący wyobrażenie zastępcze aktywizuje się dopiero wraz „powrotem” wypartej treści i polega na tym, że przedświadomość kieruje na obsadzone nieświadomą energią wyobrażenie własną energię (przeciwobsadzenie). Freud wydaje się tutaj utożsamiać akt wyparcia z „ucieczką" nieświadomej energii przed przedświadomym obsadzeniem. W efekcie tego procesu energia libidalna odrzuconego wyobrażenia odprowadzona zostaje w postaci lęku. Następnie świadomość wykorzystuje przedświadomą energię uwolnioną $\mathrm{w}$ wyniku poprzedniej operacji do obsadzenia innego wyobrażenia, które uniemożliwia pojawienie się, w miejsce tego elementu, wypartego wyobrażenia.

${ }^{74}$ Z. Freud, Nieświadomość, przeł. R. Reszke, [w:] tenże, Psychologia nieświadomości, s. $108-109$.

${ }^{75}$ Tamże, s. 109. 
Ponownie nie dowiadujemy się jednak, co jest wybierane jako przedmiot zastępczego obsadzenia energią. Sięgnijmy więc do Słownika psychoanalizy, którego autorzy wymieniają dwa typy elementów podlegających przeciwobsadeniu: 1) pochodną nieświadomego wyobrażenia (wytwór zastępczy, np. zwierzę w fobii), 2) element przeciwstawiający się wyobrażeniu nieświadomemu (np. reakcja upozorowana, troska o czystość, zwalczająca tendencje analne $)^{76}$. Pomijając powyższą - wysoce dyskusyjną - kwestię wyboru zastępczego wyobrażenia, na podstawie lektury artykułu Nieświadomość możemy stwierdzić, że pełni ono funkcję przekaźnika (czy przełącznika) energii psychicznej między systemem nieświadomości a systemami świadomość/przedświadomość oraz stanowi samodzielne źródło nieokreślonego lęku w przypadku histerii.

Trzecia faza wyparcia polega wreszcie na zahamowaniu lęku, jaki generuje zastępcze wyobrażenie. W pewnych sytuacjach skumulowana w nim energia „rozlewa” się na jego skojarzeniowe otoczenie. Pobudzenie dowolnego elementu owej „asocjacyjnej fasady” wywołuje niewielki lęk działający jak sygnał alarmowy dla przedświadomości, która ponownie wycofuje swoją energię obsadową z wyobrażenia i kieruje ją ku innym wyobrażeniom, możliwie jak najbardziej od niego oddalonym. Trzecia faza wyparcia chroni aparat psychiczny zarówno przed pobudzeniami, które płyną z wnętrza organizmu, jak i przed bodźcami zewnętrznego świata (na które zostaje wyprojektowane wewnętrzne pobudzenie - np. widok zwierzęcia w fobii reprezentujący wewnętrzny nieświadomy impuls).

Dla naszego wywodu najważniejsze wydaje się uznanie przez Freuda mechanizmu przeciwobsady (obsadzenia przeciwnego, czy przeciwstawnego wyposażenia energią) $)^{77}$ za klucz do zrozumienia sposobu funkcjonowania zarówno wyparcia właściwego, czyli wyparcia wtórnego (Nachdrängen), jak i wyparcia pierwotnego. Wyparcie pierwotne obejmuje nieświadome wyobrażenie, natomiast wyparcie właściwe odnosi się do wyobrażenia przedświadomego (odebranie energii obsadzenia przedświadomego przy jednoczesnym zachowaniu energii nieświadomej). Przeciwobsadzenie umożliwia podtrzymanie wtórnego wyparcia (w tym przypadku wymagane jest ponad-

\footnotetext{
${ }^{76}$ J. Laplanche, J. B. Pontalis, Słownik psychoanalizy, s. 253.

77 Wymienione terminy oddające niemieckie Gegenbesetzung pojawiają się w polskich przekładach pism Freuda.
} 
to odebranie obsady przedświadomej ${ }^{78}$ ), a zarazem pozwala doprowadzić do skutku i podtrzymać wyparcie pierwotne.

W histerii lękowej Gegenbesetzung pojawia się w drugiej fazie wyparcia, tworząc wyobrażenie zastępcze, a ponadto w trzeciej fazie, w której świadomość broni się za jego pomoca przed ponowną aktywizacją wyobrażenia zastępczego w ten sposób, że kieruje swoją energię (w postaci uwagi) na jego asocjacyjne otoczenie i równocześnie odprowadza z niego („zarażoną” nieświadomą energią) obsadę przedświadomą. W trzeciej fazie zachodzi właściwe, wtórne wyparcie. Wywód Freuda pozostawia jednak otwarte pytanie, czy omawiany proces dotyczy stadiów rozwoju nerwicy, czy też przedstawia mechanizm wyparcia jako takiego w obydwu jego formach (wyparcie pierwotne i wtórne). Na potrzeby dalszych analiz przyjmiemy, a przemawia za tym szerszy kontekst (wypowiedzi Freuda o wyparciu zawarte w Objaśnianiu marzeń sennych i w Wyparciu), że pierwotne wyparcie odpowiada opisanej powyżej, pierwszej i drugiej fazie procesu histerycznego wypierania impulsu popędowego , a wyparcie wtórne - fazie trzeciej.

Łącząc ustalenia artykułów Das Unbewußte i Die Verdrängung, otrzymujemy następujący rezultat: pierwotne wyparcie polegałoby, z jednej strony, na odrzuceniu przez przedświadomość wyobrażenia popędowego, a z drugiej strony na jego utrwaleniu, które powoduje, że pozostaje ono w nieświadomości w niezmienionym stanie energetycznym. W pierwszej fazie przedświadomość odrzuca zatem bezpośrednio (i nieskutecznie) nieświadomy impuls, który przekształca się $\mathrm{w}$ nieokreślony lęk. $\mathrm{W}$ istocie dopiero powstały $\mathrm{w}$ ten sposób lęk staje się tutaj głównym czynnikiem wypierającym. Następnie, kiedy wyparta treść powraca (druga faza), to znaczy, kiedy usilnie dąży do uświadomienia, ponownie rodząc lęk, przedświadomość kieruje swoją energię ku wyobrażeniu zastępczemu, dzięki czemu neutralizuje niepokój. Trzecia faza (jako wtórne wyparcie) stanowi natomiast reakcję na dalszy rozwój lęku wywołany tym, że wyparta energia przenosi się na skojarzeniowe otoczenie reprezentacji zastępczej.

W Objaśnieniu marzeń sennych dowiadujemy się ponadto, że wyparte przez przedświadomość (wyparcie pierwotne) infantylne, zakazane pragnienia tworzą niedostępny „skarb złożony ze wspomnień” i jako takie stanowią warunek wstępny wyparcia ${ }^{79}$. Freud postuluje w tym miejscu dodatkowy

${ }^{78}$ Por. Z. Freud, Nieświadomość, przeł. R. Reszke, [w:] tenże, Psychologia nieświadomości, s. $107-108$.

${ }^{79}$ Tenże, Objaśnianie marzeń sennych, s. 506. 
czynnik wyparcia - pozytywną siłę przyciągania ze strony wypartych treści. Paradoksy implikowane przez ten postulat omówimy w drugiej części arty$\mathrm{kułu}^{80}$, tutaj wskażemy jedynie podstawową komplikację, której nie da się wyjaśnić w ramach teorii psychoanalitycznej.

Przedstawiony powyżej wywód Freuda prowadzi do wniosku, że powstanie "przyciągającego bieguna” wypartej treści zakłada jej utrwalenie (die Fixierung) w nieświadomości (wyparte wyobrażenie zostaje wyposażone w stały ładunek energetyczny i nie podlega żadnym zmianom). Utrwalenie może jednak nastąpić wyłącznie w systemach świadomość/przedświadomość, gdzie energia psychiczna podlega „związaniu” za pośrednictwem struktur językowych. Na poziomie procesu pierwotnego mamy bowiem do czynienia ze swobodnym przepływem energii psychicznej „uporządkowanej” jedynie według praw przesunięcia i zagęszczenia, które dopuszczają duży stopień płynności nieświadomych wyobrażeń.

Jak pamiętamy, w artykule Nieświadomość Freud podkreśla, że podstawowym kryterium odróżniającym proces wtórny od pierwotnego jest możliwość „przekładu” wyobrażeń rzeczowych na słowa. To jednak zakłada, że utrwalenie czy związanie energii za pomocą wyobrażeń słownych (przeciwobsadzenie) musi być poprzedzone jakąś formą utrwalenia wyobrażeń rzeczy, a zatem jakąś formą wiedzy o treściach, które powinny zostać wyparte. Problematyczność tego założenia dotyczy oczywiście tylko wyparcia pierwotnego, w którym reprezentacja popędu pojawia się w czystej (nieujęzykowionej) postaci, a co najważniejsze, w którym to dopiero konstytuuje się sam podział na proces pierwotny i wtórny. Odmowa przełożenia wypartego pragnienia (wyobrażenia rzeczy) na słowa implikuje, że stanowi ono pewną ustrukturyzowaną jednostkę (niejęzykowego) sensu.

Jeśli zgodzimy się z Freudem, że pierwsze pragnienia (rdzeń naszej istoty) konstytuują proces pierwotny, a pierwotne wyparcie stanowi podstawę aktywizacji procesu wtórnego, to będziemy zmuszeni wówczas wyprowadzić stąd wewnętrznie sprzeczną konkluzję, że pierwotne wyparcie jest jednocześnie źródłem i skutkiem procesu wtórnego. Weryfikację zasadności tego zarzutu podejmiemy w drugiej części artykułu. W tym celu przeprowadzimy tam bardziej szczegółową analizę teorii wyparcia pierwotnego oraz pojęcia utrwalenia.

${ }^{80}$ Por. drugą część artykułu w niniejszym numerze czasopisma. 


\section{Rekapitulacja}

Dla jasności wywodu streścimy i podsumujemy wyniki analiz przeprowadzonych w niniejszej, pierwszej, części artykułu. Na samym początku wskazaliśmy sprzeczność pomiędzy dwoma freudowskimi ujęciami wyparcia: według pierwszego $\mathrm{z}$ nich wyparcie polega na całkowitym wykluczeniu patogennego impulsu z obszaru świadomości, według drugiego zaś, wyparcie pozbawia odrzucany impuls energii emocjonalnej, ale nie odcina go od świadomości. Lektura tekstów źródłowych traktujących o tej problematyce pokazała, że Freud skłaniał się bardziej do pierwszego ujęcia. W artykule Nieświadomość odnaleźliśmy ważne uzupełnienie teorii wyparcia w postaci tezy, że odrzucenie zakazanego impulsu sprowadza się do uniemożliwienia przekładu wyobrażeń rzeczy na wyobrażenia słowne. Główny paradoks związany z tym uzupełnieniem wynika stąd, że zakłada ono istnienie intencji skierowanej ku temu, co ma być wyparte. Zarówno w przypadku, gdy intencja ta jest nieświadoma, jak i wtedy, gdy jest świadoma (Freud nie precyzuje tej kwestii), akt wyparcia nie daje się jednak wytłumaczyć w ramach teorii psychoanalitycznej. W pierwszym przypadku (nieświadoma intencja) wyparcie miałoby bowiem całkowicie irracjonalny, przypadkowy charakter. Natomiast w drugim przypadku wyparcie nie byłoby po prostu możliwe, ponieważ akt świadomego „niechcenia czegoś" zachowuje potencjalny dostęp do tego, co niechciane (np. za pośrednictwem pamięci), a zatem z góry wyklucza możliwość „wykluczenia” zakazanego wyobrażenia $\mathrm{z}$ obszaru świadomości. Wskazana sprzeczność pojawia się w rozmaitych wariantach teorii wyparcia, znajdziemy ją w topicznym modelu psychiki, gdzie Freud lokalizuje cenzurującą instancję w systemie przedświadomości, sugerując, że opiera się ona na uwadze i pamięci. Sprzeczność ta pojawia się również w „strukturalnym” modelu psychiki, gdzie za wyparcie odpowiada opór stawiany przez Nad-Ja (superego), który jest niedostępny Ja.

W „energetycznym” ujęciu kluczowym mechanizmem odpowiedzialnym za wyparcie w jego dwóch podstawowych formach (wyparcie wtórne i pierwotne) okazało się przeciwobsadzenie (Gegenbesetzung) przedświadomą energią „reprezentacji zastępczej” (wyobrażenia reprezentującego wyparte pragnienie). Freud nie wyjaśnia jednak, według jakich kryteriów zostaje dokonany „wybór” takiego, a nie innego wyobrażenia do „roli” reprezentanta ukrytego życzenia. 
„Energetyczna” wersja teorii wyparcia zostaje doprecyzowana na przykładzie rozwoju histerii lękowej, w której Freud wyróżnia trzy stadia wyparcia. W pierwszej fazie przedświadomość odrzuca bezpośrednio (i nieskutecznie) nieświadomy impuls, który przekształca się w nieokreślony lęk będący tutaj głównym czynnikiem wypierającym. W drugiej fazie, kiedy wyparta treść powraca, to znaczy, kiedy ponownie dąży do uświadomienia, rodząc lęk, przedświadomość kieruje swoją energię ku wyobrażeniu zastępczemu, dzięki czemu neutralizuje niepokój. Analizując powyższy proces w szerszym kontekście intertekstualnym, ustaliliśmy, że pierwsza i druga faza odpowiada wyparciu pierwotnemu. Trzecia faza jako wtórne wyparcie stanowi natomiast reakcję na dalszy rozwój lęku wywołany tym, że wyparta energia przenosi się na skojarzeniowe otoczenie reprezentacji zastępczej.

Również w czysto ekonomicznym opisie wyparcia natknęliśmy się na wskazane wcześniej sprzeczności i szereg dodatkowych problemów interpretacyjnych, z których najważniejszy dotyczy fundamentalnego dla psychoanalizy mechanizmu wyparcia pierwotnego (problematyczność założenia wypierającej i interpretującej instancji, która funkcjonuje bez udziału procesu wtórnego). To zagadnienie podejmiemy w drugiej części artykułu.

\section{Bibliografia}

Dybel P., Psychoanaliza - ziemia obiecana? Dzieje psychoanalizy w Polsce 1900-1989. Część pierwsza: Okres burzy i naporu, Kraków 2016.

Freud Z., Analiza skończona i nieskończona, tłum. J. Prokopiuk [w:] tenże, Z. Freud, Poza zasada przyjemności, Warszawa 2000, s. 157-190.

Freud Z., Dowcip i jego stosunek do nieświadomości, przeł. R. Reszke, Warszawa 1993. Freud Z., Ego i id, przeł. J. Prokopiuk, [w:] Z. Rosińska, Freud, Warszawa 2002, s. 295-334.

Freud Z., Fetyszyzm, przeł. R. Reszke, [w:] tenże, Psychologia nieświadomości, Warszawa 2009, s. 303-310.

Freud Z., Histeria i lęk, przeł. R. Reszke, Warszawa 2001.

Freud Z., Kultura jako źródło cierpień, przeł. R. Reszke, Warszawa 1995.

Freud Z., Nieświadomość, przeł. M. Poręba, [w:] Z. Rosińska, Freud, Warszawa 2002, s. 193-225.

Freud Z., Nieświadomość, przeł. R. Reszke, [w:] tenże, Psychologia nieświadomości, Warszawa 2009, s. 89-130.

Freud Z., Objaśnianie marzeń sennych, przeł. R. Reszke, Warszawa 1996. 
Freud Z., Poza zasada rozkoszy, przeł. R. Reszke, [w:] tenże, Psychologia nieświadomości, Warszawa 2009, s. 161-216.

Freud Z., Uwagi na temat dwóch zasad procesu psychicznego, przeł. R. Reszke, [w:] tenże, Psychologia nieświadomości, Warszawa 2009, s. 5-14.

Freud Z., Uwagi na temat pewnego przypadku nerwicy natręctw, przeł. R. Reszke, [w:] tenże, Charakter a erotyka, Warszawa 2009, s. 23-82.

Freud Z., Wstęp do psychoanalizy, przeł. S. Kempnerówna, W. Znaniecki, Warszawa 2000.

Freud Z., Wykłady ze wstępu do psychoanalizy. Nowy cykl, przeł. P. Dybel, Warszawa 1995.

Freud Z., Wyparcie, przeł. M. Poręba, [w:] Z. Rosińska, Freud, Warszawa 2002, s. 259-269 .

Freud Z., Wyparcie, przeł. R. Reszke, [w:] tenże, Psychologia nieświadomości, Warszawa 2009, s. 77-88.

Freud Z., Zarys psychoanalizy, przel. J. Prokopiuk, [w:] tenże, Poza zasada przyjemności, Warszawa 2000, s. 99-156.

Gadamer H. G., Koło jako struktura rozumienia, przeł. G. Sowinski, [w:] tenże, Wokót rozumienia. Studia i szkice z hermeneutyki, Kraków 1993, s. 227.

Kant I., Antropologia w ujęciu pragmatycznym, przeł. E. Drzazgowska, P. Sosnowska, Warszawa 2005.

Laplanche J., Pontalis J. B., Stownik psychoanalizy, przeł. E. Modzelewska, E. Wojciechowska, Warszawa 1996.

Nietzsche F., Z genealogii moralności. Pismo polemiczne, przeł. L. Staff, Kraków-Warszawa 1906.

Ricoeur P., O interpretacji. Esej o Freudzie, przeł. M. Falski, Warszawa 2008, s. 321-386 .

Rosińska Z., Freud, Warszawa 2002.

Roudinesco É., Plon M., Wörterbuch der Psychoanalyse, przeł. Ch. Eissing-Christophersen, M. Müllerburg, R. Nentwig, M. Ramaharomanana, F. Roelcke, M. Wiesmüller, Wien 2004.

Schopenhauer A., Świat jako wola i przedstawienie, t. 2, przeł. J. Garewicz, Warszawa 1995.

\section{Abstract}

The Paradoxes of Freud's Theory of Repression. Part 1

The Article attempts to reconstruct the theory of repression Sigmund Freud. The starting point is to demonstrate the contradictions between two different shots of repression: on the one hand, the repression is based on the total 
exclusion of pathogenic impulse from the consciousness, on the second hand, the repression deprives the rejected impulse of emotional energy, but does not cut it from consciousness. The rest of this article discusses the paradoxes that appear in the topiographical and economic model of the psyche.

Key words: the repression, the trauma, the anticathexis, the unconscious, the preconscious, the censorship, the thing presentations, the word presentations, the ego, the id, the superego 